\title{
Growth, growth factors and diabetes
}

\author{
Francesco Chiarelli, Cosimo Giannini and Angelika Mohn \\ Department of Pediatrics, University of Chieti, Italy \\ (Correspondence should be addressed to F Chiarelli, Clinica Pediatrica, Ospedale Policlinico, Via dei Vestini, 5, 66013 Chieti, Italy; \\ Email: chiarelli@unich.it)
}

\begin{abstract}
Type 1 diabetes mellitus (T1DM) and other chronic diseases in children are well known to adversely affect linear growth and pubertal development. In the years immediately following the introduction of insulin therapy, short stature was consistently reported in children with T1DM. However, over the past 50 years significant improvement in the prognosis for growth and final height in children with diabetes has been achieved. Although pre-pubertal and post-pubertal growth are important phases in growth, puberty and its related hormonal changes represent a critical phase for growth gain and final height particularly in patients with T1DM. Growth impairment reported in diabetic patients is dependent on abnormalities in physiological bone growth and corresponds to abnormalities of the growth hormone-insulin-like growth-I (GH-IGF-I) axis. These alterations seem to be related to appropriate insulin levels and thereby to glycaemic control as judged by haemoglobin levels. Modern diabetes care, particularly intensified insulin regimens, might improve metabolic control in patients with T1DM, therefore preventing abnormalities of the GH-IGF-I axis and leading to normal growth and final height similar to that of their unaffected peers.
\end{abstract}

European Journal of Endocrinology 151 U109-U117

\section{Growth, growth factors and diabetes}

Type 1 diabetes mellitus (T1DM) and other chronic diseases are well known to adversely affect linear growth and pubertal development. Although Mauriac syndrome (1), the most important expression of growth alteration due to severe insulin deficiency in diabetic patients, is now rare, impaired growth in children with T1DM is still reported. This is particularly true in patients with poor metabolic control $(2,3)$. However, with the more recent insulin treatment regimens based on multiple daily injections and adjustment of insulin doses according to blood glucose levels, growth has substantially improved (4) and height in children with T1DM today is similar in all ages to the height of their unaffected peers.

The aim of this paper is to review growth and development in children with T1DM and recent advances in linear growth achieved by improvement in metabolic control.

\section{Growth and development}

Over the last several years many studies have been performed in order to clarify the mechanism by which insulin deficiency influences growth in patients with T1DM in order to improve final height in these patients.

Longitudinal bone growth is a complex phenomenon involving a multitude of regulatory mechanisms strongly influenced by growth hormone (GH) (5-8).
$\mathrm{GH}$ has a pulsatile secretion with age-dependent concentrations characterised by low secretion in the prepubertal period, a rise at puberty and a decrease in old age. Most of the $\mathrm{GH}$ promoting effects on growth are mediated through the actions of peptides, the insulin-like growth factors IGF-I and IGF-II, mainly secreted by the liver. IGFs circulate bound to specific insulin-like growth factor binding proteins (IGFBPs), six of which have been identified. IGFBP-3 is the major circulating IGFBP during post-natal life and is GH-dependent. IGFBP-3 prolongs the half-life of IGFs and carries IGFs to the target tissues making a ternary complex with acid labile subunit (ALS), thereby having a pivotal role in the regulation of skeletal growth $(9-11)$.

Insulin is an important regulator of this complex. Infact, adequate insulin secretion and normal portal insulin concentrations are needed to support normal serum concentrations of IGFs and IGFBPs and indirectly to promote growth. Several studies have clearly demonstrated that insulin modulates the hepatic GH receptor expression and post receptor events $(12-14)$ thereby influencing the serum concentrations of IGFs and IGFBPs. Furthermore, insulin modulates gene expression and secretion of IGFBP-1, one of the most important negative regulators of IGF-I bioactivity (15-17). Portal insulin deficiency is therefore directly responsible for $\mathrm{GH}$ hypersecretion, low circulating levels of IGF-I and IGFBP-3, and high circulating levels of IGFBP-1 seen in children with T1DM independently of puberty, and represents one of the 
most important underlying causes of growth failure in T1DM (18).

Portal insulin concentrations play a critical role in the induction of $\mathrm{GH}$ and insulin resistance reported in children with T1DM. In vitro studies indicate that insulin may indirectly regulate the enhancement of $\mathrm{GH}$ serum concentration either by direct regulation of the hepatic GH receptor or by a permissive effect on postreceptor events $(12-14)$.

In vivo studies have demonstrated alterations in serum GH binding protein concentrations which are considered a putative index of $\mathrm{GH}$ receptor number $(19,20)$. Studies in newly diagnosed subjects with T1DM demonstrated a decrease in circulating concentrations of $\mathrm{GH}$ binding protein, which subsequently increase with the introduction of insulin therapy, although levels remain lower than those reported in normal subjects (21). Low GH receptor expression and anomalies in post-receptorial events induce $\mathrm{GH}$ hypersecretion, amply reported in children with T1DM which is the clearest expression of GH resistance in children with T1DM.

Abnormalities in the GH-IGF-I axis and particularly high GH serum concentrations may be considered one of the most relevant factors in insulin resistance detected in children with T1DM. Relevant results to clarify GH-dependent insulin resistance have been reported in hybrid mice, resulting in liver IGF-I-deficient (LID) and GH antagonist (GHa) action (22). Some authors have shown that inactivation of $\mathrm{GH}$ action leads to decreased blood glucose levels; it has been reported that both blood glucose levels and serum insulin concentrations in the fasting state in LID + GHa mice are dramatically reduced compared with control and LID mice expressing only the lack of GH action. Furthermore, the insulin tolerance test showed a state of insulin insensitivity in LID mice that is detected in $\mathrm{LID}+\mathrm{GHa}$ mice, demonstrating that lack of $\mathrm{GH}$ action may improve peripheral insulin sensitivity thus underlying the main role of chronic high $\mathrm{GH}$ levels in insulin resistance in patients with T1DM (22).

The widely reported increases in baseline GH concentrations, GH pulse frequency and amplitude in patients with diabetes have profound anti-insulin effects (23) similar to healthy subjects, resulting in increased blood glucose concentrations associated with decreased peripheral insulin sensitivity despite higher levels of insulin secretion, increased hepatic glucose production, stimulation of lipolysis and decreased insulin-stimulated glucose uptake in muscle (24). In healthy subjects exogenous $\mathrm{GH}$ administered at physiological levels causes insulin resistance, by impairing the ability of insulin to suppress hepatic glucose utilisation (25). This hyperglycaemic effect is characterised by reduced insulin receptor binding affinity, as well as a probable post-receptor defect $(25,26)$. Thus, the development of insulin resistance in subjects with normal beta-cell function is associated with a compensatory increase in insulin secretion which allows the continued maintenance of normal glucose tolerance (27). In subjects with T1DM, similar effects have been demonstrated by the increased insulin requirement during clamp studies. In fact, using an overnight variable rate insulin infusion euglycaemic clamp protocol, some authors have shown a positive relationship between peripheral insulin sensitivity and overnight GH concentrations attributable to the effect of $\mathrm{GH}$ on peripheral glucose metabolism (28). In fact, a positive linear correlation to variations in $\mathrm{GH}$ serum concentrations has been described. The increased GH levels result in hyperglycaemia which leads to the increased overnight insulin requirements characteristic of the "dawn phenomenon' (29).

Although many studies have been performed to clarify the links between GH hypersecretion and peripheral insulin sensitivity in T1DM, the molecular mechanism has not yet been clarified. Although structurally different, activation of both GH receptor (GHR) and insulin receptor (IR) seems to converge at postreceptorial levels partly explaining the anti-insulin effect of GH. In fact, $\mathrm{GH}$ and insulin can stimulate phosphorylation of Shc (30-32), an adaptor protein that interacts with the growth factor receptor and activates the Ras-Raf-MAP kinase (MAPK) signalling pathway. GH may activate the p90 $0^{\mathrm{RSK}}$, S6 kinase, most likely through MAPK (33). Furthermore, some studies showed that $\mathrm{GH}$ can promote tyrosine phosphorylation of the IR substrate-1 (IRS-1) and IRS-2 proteins by activation of JAK2 $(34,35)$. Another mechanism that may be involved in decreased GH-dependent insulin sensitivity is the increased concentrations of suppressors of cytokine signalling (SOCS). In fact, both insulin-induced IRS-1-p85 interactions and MAPK and AKT activation seem to be affected by expression of SOCS-1, -3 and -6 (36-40). Furthermore, it has been demonstrated that SOCS-1 and -3 may bind IRS-1 and -2 and promote their degradation (41). Recent studies performed in SOCS-1-deficient mice demonstrate a prolonged IRS-1 phosphorylation following insulin treatment that results in a state of enhanced insulin sensitivity (42). In contrast, the dramatic decrease in IRS-1 and -2 levels induced by adenoviraldriven expression of SOCS-1 in the liver of mice results in the insurgence of hyperglycaemia, hyperinsulinaemia and insulin resistance (41).

Evidence now exists that anomalies in GH secretion and tissue-specific alterations in IGF bioavailability may be involved in many of the diabetes-related complications (43). Prevention of short- and long-term GHIGF-I axis abnormalities in T1DM is important in the development of therapeutic modalities aimed not only at improving metabolic control but also in preventing the vascular complications associated with T1DM. Therefore, several studies with exogenous recombinant human (rh) IGF-I in association with insulin therapy have been performed. Exogenous rhIGF-I 
administration has clearly been shown to restore the GH-IGF-I axis, to improve insulin sensitivity and to reduce insulin requirements for euglycaemia (44-47). However, new studies seem to point to the deleterious effect of high IGF-I levels in the development of microvascular complications. In fact, IGF-I plays a critical role in the development of diabetic retinopathy (48) and nephropathy (43) mainly through stimulation of epithelial and retinal growth factors (vascular endothelial growth factor (VEGF), endothelial nitric oxide (eNOS), endothelin-1 (ET-1)). Kondo et al. (49) have clearly shown that IGF-I receptors in the endothelial cells are involved in the proliferative response to relative hypoxia. Reproducing an experimental condition that can simulate in animal models the neovascularisation seen in the diabetic retina, they found that under normoxic conditions the retinas of mice develop normally in the absence of endothelial IR/IGF-I receptor (IGF$1 \mathrm{R})$. In conditions of relative hypoxia in the presence of IR/IGF-1R endothelial expression, through increased levels of VEGF, eNOS and ET-1 develop neovascularization which are not reported in neonatal knockout mice of IR/IGF-IR on vascular endothelial cells (49).

We have demonstrated that microalbuminuric patients have higher levels of both urinary and plasma IGF-I than normoalbuminuric diabetic subjects (50). Furthermore, IGF-I seems to enhance VEGF production, a cytokine with angiogenic effects implicated in the pathogenesis of vascular-related disease. In previous studies we have reported increased serum VEGF levels in pre-school, pre-pubertal, and particularly pubertal patients with diabetes compared with controls. These increased levels are reported to be related to the severity of nephropathy and retinopathy in adolescents and young adults with onset of diabetes during childhood (51). Furthermore, elevated serum VEGF levels seem to be related to the development of persistent microalbuminuria, making this a possible predictor and risk factor for microalbuminuria and incipient diabetic nephropathy in adolescents and young adults with onset of diabetes during childhood (52).

These data led us to propose a dual insulin-GH antagonist therapy association in order to prevent and restore GH-IGF-I axis anomalies. In fact, the reduction of an anti-insulin $\mathrm{GH}$-dependent effect and intensified therapy may prevent insulin insensitivity and GH-IGF-I axis abnormalities in children, resulting in both a better metabolic control and the prevention of diabetes-related complications.

\section{Height at onset, pre-pubertal growth and growth factors}

Despite the fact that height at diagnosis has been studied extensively, many controversies remain. While some studies observe that children with diabetes are taller than controls at diagnosis $(2,53-58)$ others report normal or lower height in children with newly diagnosed diabetes $(3,59,60)$. The most important factor influencing this evaluation is the reference data that may be severely influenced by age trend variations. Brown et al. (61) showed that height standard deviation score (Ht SDS) at diagnosis in a group of 140 children with T1DM diagnosed between 1969 and 1990 was +0.29 consistent with the mean height SDS of control children in the same area. Detailed analysis revealed, however, that this was true only for children aged 5-10 years at diagnosis who were taller $(\mathrm{Ht}$ SDS \pm S.D. $0.58 \pm 1.14$ versus $0.31 \pm 0.90 ; P<0.05)$. In contrast, those diagnosed under the age of 5 were shorter (Ht SDS 0.12 \pm 0.93 ) and those aged more than 10 years at diagnosis were similar in size (Ht SDS $0.22 \pm 0.98$ ) to controls (61). Similar data have been reported by other authors (62). It has also been shown that height at diagnosis in a group of 89 children with duration of diabetes of more than 3 years and a mean age of $8.9 \pm 2.2$ years was not different compared with 102 healthy control children (63). In a longitudinal study, it has been shown that height at diagnosis in a total of 436 children with diabetes was significantly above the reference population. Furthermore, it has been shown that when newly diagnosed patients were stratified into quartiles according to age-at-onset, excess height tended to be more pronounced in those patients who developed diabetes at an older age (58).

Unlike this controversy about height at diagnosis, a greater consensus has been found regarding growth gain after diagnosis. In fact, a reduction in height SDS between diagnosis and the onset of puberty has consistently been reported. A reduction in height SDS over the first 3 or 4 years after diagnosis is common. Brown et al. demonstrated that pre-pubertal growth is compromised by a change in height SDS between diagnosis and the onset of the pubertal spurt of -0.20 (range 0.48 to -1.05 , paired $t=2.38$ ) and a 0.06 SDS mean loss of height per year between diagnosis and the onset of puberty (61). Loss in height SDS seems to be strongly affected by metabolic control. Gunczler et al. showed that childen with poor control have a significantly lower growth velocity compared with well controlled subjects (64). Although there is a greater agreement on height loss after diagnosis of diabetes, Du Caju et al. showed a normal pre-pubertal growth, as a similar height SDS at the age of 7 and 10 has been reported (60).

The alterations in height SDS in the pre-pubertal age seem to be strongly linked to abnormalities in the hypothalamo-pituitary-IGF-I axis $(65,66)$. Munoz et al. showed that during the pre-pubertal stage, serum IGF-I levels in 41 patients with T1DM were significantly lower than those in control subjects (67). Similar data were reported by Taylor et al. and Rogers et al. confirming abnormalities in the GH-IGF-I axis in pre-pubertal children with diabetes $(68,69)$. 
Furthermore, IGF-I serum levels seem to be strongly linked to the degree of metabolic control. In fact, several studies have reported that diabetic children with inadequate metabolic control show a tendency towards lower IGF-I levels than children with adequate metabolic control (65-70) with a negative correlation with HbA1c plasma levels $(66,67)$. Serum insulin concentrations achieved by exogenous insulin therapy play an important role in the reduction of IGF-I in serum (71). In fact, it is clearly demonstrated that low IGF-I levels are closely related to insulin deficiency, and improved insulin delivery during intensified treatment invariably leads to improved circulating levels of IGF-I $(72,73)$. These alterations in the GH-IGF axis are associated with abnormalities in IGFBP serum concentrations. Several studies have demonstrated that median IGFBP-3 serum concentrations are significantly lower in children with diabetes when compared with controls $(74-76)$.

\section{Growth at puberty}

Similar to healthy adolescents, the pubertal growth spurt represents the most critical phase for linear growth and final height in children with T1DM. The pubertal phase is characteristically associated with a reduction in insulin sensitivity, which is known to be more severe in patients with T1DM, and might negatively influence growth and height gain $(77,78)$. Poor compliance with diet and insulin therapy may be considered to be important factors influencing the deterioration in metabolic control. However, the endocrine changes at puberty play a significant role in glycaemic control during pubertal development (79). In fact, puberty is characteristically associated with a rise in $\mathrm{GH}$ pulse amplitude, and mean overnight $\mathrm{GH}$ concentrations have been shown to be much higher in adolescents with T1DM than in control subjects (80-82). The elevated serum GH levels have been suggested to be the most important mechanism involved in high insulin requirement and poor metabolic control. Furthermore, it is clearly demonstrated that increased serum GH concentrations, characteristically associated with the onset of puberty in healthy subjects (83), increase insulin resistance in adolescent patients with diabetes, being more insulin resistant at all pubertal stages (84). Relative insulin resistance associated with increased serum GH concentrations and low serum IGF-I levels and bioactivity have a significant negative impact on glycaemic control during this period and poor glycaemic control appears to be of importance for growth deficit. In fact, Danne et al. showed a direct correlation between increased glycosylated haemoglobin levels and standing height SDS reduction $(85)$.

In contrast to previous studies (86) which reported delayed puberty in children with diabetes, several recent studies have shown that the timing and duration of the pubertal growth spurt is normal in adolescents with diabetes $(61-87)$. Although the chronological age at onset of puberty and the duration of the pubertal growth spurt is not significantly different between subjects with T1DM and healthy adolescents, several studies have shown a blunted pubertal growth spurt which seems to be associated with a reduced peak of height velocity SDS $(2,60,61,86,88,89)$.

Sex and age at diagnosis seem to be the most important factors for an impaired growth spurt in adolescents with diabetes. Brown et al. showed that the mean peak height velocity SDS ( \pm SDS) in the Oxford study was $-1.09 \pm 1.02$ in girls and $-0.50 \pm 1.14$ in boys (61). Similar data were reported by Salardi et al. who showed a mean total pubertal height gain of $14.9 \mathrm{~cm}$ in diabetic girls and a mean of $18.7 \mathrm{~cm}$ in boys (2). These data suggest that the mean peak height velocity SDS is more impaired in adolescent girls with diabetes than in boys.

Furthermore, patients with onset of type 1 diabetes under the age of five showed the greatest loss of height during puberty (61) and an association between poor relative growth and younger age at onset was reported (85). These findings are in contrast with data reported by Salardi et al. who showed an impaired growth spurt only in those girls diagnosed at or around puberty, but normal growth in younger children (2).

Impaired pubertal growth is supported by abnormal serum concentration of IGF-I and IGFBPs. IGF-I levels were reported to be reduced in both girls and boys with T1DM (67-90). Ahmed et al. showed that at peak height velocity IGF-I was significantly reduced in boys and girls with T1DM (87). Taylor et al. reported that, similar to healthy subjects, IGF-I levels increase during puberty both in boys and girls with diabetes (68). However, in both sexes patients with T1DM have significantly lower serum IGF-I levels compared with controls. In a large cross-sectional study Clayton et al. demonstrated that the rise in IGF-I levels during puberty was blunted only in girls with diabetes. However, it has been shown that serum IGF-I levels were lower in children with diabetes than the levels detected in control subjects in both boys and girls at each pubertal stage (91).

These alterations in the GH-IGF axis are associated with abnormalities of the IGFBPs. In fact, IGFBP levels are altered in children with T1DM and, specifically, levels of the large molecular weight IGFBP-3 have been demonstrated to be significantly lower in the serum of adolescents with T1DM compared with controls $(75,76)$.

Alterations in the GH-IGF-I axis represented by low IGF-I and IGFBP-3 levels play an important role in the pathogenesis of pubertal growth failure in diabetes and have been demonstrated to be related to insulin deficiency. Several studies have clearly shown that glycaemic control strongly influences IGF-I levels after the onset of puberty (69). Furthermore, data reported in 
several studies showed that in both sexes, IGF-I levels are closely related to insulin dose (91-93); nonetheless, improved insulin therapy invariably leads to improved circulating levels of IGF-I $(72,73)$ showing the great importance of serum insulin concentrations on the GH-IGFs axis regulation and the effectiveness of intensive insulin therapy on restoration of GH-IGF-I axis alterations especially in the pubertal phase.

\section{Final height}

Although loss of height from the onset of diabetes has been widely reported, an impaired final height has not been reported in children with type 1 diabetes. In fact, while some studies, especially those performed in the pre-intensive insulin therapy era, showed an impaired final height in children with diabetes (3), more recent studies show a normal or only slightly reduced final height (2, 58, 60, 61-94). Holl et al. reported a normal final height in a group of 76 patients with T1DM (58). Similar data were reported by Du Caju et al. who showed normal final height in boys with diabetes while only a slightly reduced final height was reported in girls (60). Furthermore, the final height of 80 children studied in Oxford was - 0.06 SDS, which did not differ significantly from their mid parental height SDS (61).

The age at onset of T1DM and metabolic control are widely reported to be the most important factors affecting final height and for predicting adult height in children with diabetes (85). In fact, it has been shown in twins that when diabetes is diagnosed before puberty, final height of the twin with T1DM was lower compared with the healthy co-twin. Furthermore, Brown et al. reported that early onset of diabetes in the preschool years seems to be related with a slightly reduced final height (61). Holl et al. confirmed these data by showing that longitudinal growth reduction was more pronounced in patients diagnosed before puberty and that final height in patients with pre-pubertal diabetes onset was significantly lower compared with patients with pubertal or post-pubertal onset of diabetes (58).

Metabolic control has been shown to be a significant factor influencing final height. Holl et al. (95) clearly demonstrated that in paediatric patients with prepubertal diabetes onset, especially those with poorly controlled diabetes mellitus, a significant reduction in height is seen compared with subjects with good control. The importance of metabolic control in predicting height loss in children with T1DM is clearly demonstrated by data reported by Donaghue et al. (4) in a recent retrospective analysis study of growth in a total of 451 children and adolescents with diabetes diagnosed between 1974 and 1990. They showed that after 5 years of diabetes duration, height SDS loss correlated with higher glycosylated haemoglobin and fewer insulin injections. Furthermore, an improvement in height gain was found in children diagnosed after 1995 compared with those diagnosed between 1974 and 1995. Although height SDS and age at diagnosis were not different, children with T1DM diagnosed between 1974 and 1990 were significantly shorter than children diagnosed between 1991 to 1995 after five years of diabetes duration (4).

\section{GH-IGF-I axis in children with intensive insulin therapy}

Improvements in diabetes care and management and especially newer insulin schedules based on multiple daily injections have led to a reduction in diabetic complications and seem to ameliorate growth in children with T1DM. This might be due to normalisation of the GH-IGF-I axis.

We have therefore studied the GH-IGF-I axis in children and adolescents with T1DM treated with intensive therapy (using four daily insulin injections) from the onset of diabetes. Thirty male children and adolescents with T1DM were enrolled and were compared with a group of 30 healthy subjects matched for age, sex and pubertal age; they were divided into three groups: prepubertal (group 1), pubertal (group 2) and post-pubertal (group 3) subjects (Tables 1 and 2). In both pre-pubertal and pubertal children mean $\mathrm{HbA1c}$ values were compatible with optimal metabolic control achieved by intensive therapy. Moreover, it is important to stress that an effective insulin therapy regime may anticipate and control $\mathrm{HbA1c}$ alterations which usually increase at the onset of puberty. In fact, in pubertal and post-pubertal children, HbAlc, although statistically significantly higher than in control groups, was lower than the optimal control values recommended by the Diabetes Control and Complication Trial (DCCT). Optimal metabolic

Table 1 Age, diabetes duration and insulin requirement in pre-pubertal (group 1), pubertal (group 2) and post-pubertal (group 3) children with T1DM and in age-matched controls.

\begin{tabular}{|c|c|c|c|c|c|c|}
\hline & \multicolumn{2}{|c|}{ Group 1} & \multicolumn{2}{|c|}{ Group 2} & \multicolumn{2}{|c|}{ Group 3} \\
\hline & T1DM & $\overline{\text { Controls }}$ & T1DM & Controls & T1DM & Controls \\
\hline Age (years) & $10.3 \pm 2.0$ & $9.5 \pm 2.72$ & $13.8 \pm 1.1$ & $12.0 \pm 1.16$ & $18.5 \pm 1.3$ & $19.7 \pm 4.6$ \\
\hline Diabetes duration (years) & $6.5 \pm 3.0$ & & $5.1 \pm 4.2$ & & $5.8 \pm 3.7$ & \\
\hline Insulin requirement (U/kg) & $0.9 \pm 0.2$ & & $1.01 \pm 0.3$ & & $1.07 \pm 0.35$ & \\
\hline
\end{tabular}


Table 2 Height SDS, IGF-I, IGFBP-3, body mass index, HbA1c, cholesterol and triyglycerides in pre-pubertal (group 1), pubertal (group 2) and post-pubertal (group 3) children with T1DM and in age-matched controls.

\begin{tabular}{|c|c|c|c|c|c|c|c|c|c|}
\hline & \multicolumn{3}{|c|}{ Group 1} & \multicolumn{3}{|c|}{ Group 2} & \multicolumn{3}{|c|}{ Group 3} \\
\hline & T1DM & Controls & $P$ & T1DM & Controls & $P$ & T1DM & Controls & $P$ \\
\hline Heigh & $0.68 \pm 0.9$ & $0.46 \pm$ & 0.76 & $0.15 \pm 1.6$ & 0.17 & 0.12 & $0.19 \pm 0.8$ & $0.18 \pm 0.7$ & 0.63 \\
\hline IGF-I (ng/ml) & $180.3 \pm 120.14$ & $+176.6 \pm 42.63$ & 0.82 & $379.8 \pm 146.1$ & $471 \pm 166$ & 0.27 & $364 \pm 144.3$ & $352.9 \pm 53.1$ & 0.9 \\
\hline IGFBP-3 (ng/ml) & $3022 \pm 902.2$ & $3173 \pm 623$ & 0.46 & $3376.3 \pm 427.4$ & $4116.2 \pm 703.5$ & 0.34 & $3364.6 \pm 605.2$ & $3772.9 \pm 254.8$ & 0.52 \\
\hline $\begin{array}{l}\text { Body mass index } \\
\left(\mathrm{kg} / \mathrm{m}^{2}\right)\end{array}$ & $19.8 \pm 3.3$ & $21.4 \pm 8.1$ & 0.89 & $21.7 \pm 2.4$ & $20.8 \pm 4.1$ & 0.46 & $23.1 \pm 9.2$ & $24.1 \pm 6.7$ & 0.48 \\
\hline $\mathrm{HbA1c}(\%)$ & $7=$ & $4.9 \pm 0$ & $<0.001$ & $7.1=$ & $5.0 \pm$ & $<0.001$ & 6.8 & 5.0 & $<0.001$ \\
\hline Cholesterol (mg/dl) & $150.3 \pm 22.6$ & $187.7 \pm 65.2$ & 0.31 & $145.8 \pm 13.7$ & $154.6 \pm 19.3$ & 0.30 & $141.7 \pm 18.9$ & $135.5 \pm 26.9$ & 0.34 \\
\hline Triglycerides (mg/dl) & $52.4 \pm 18.2$ & $86.6 \pm 32.3$ & 0.57 & $57.9 \pm 28.1$ & $79.5 \pm 21.9$ & 0.02 & $73.5 \pm 31.5$ & $80.3 \pm 31.6$ & 0.56 \\
\hline
\end{tabular}

control, achieved in different pubertal and growth phases in diabetic patients, seems to positively influence the GH-IGF-I axis. No statistically significant differences in IGF-I and IGFBP-3 serum concentrations were detected in the three diabetic groups compared with control subjects, suggesting normal function of the GH-IGFI axis in children with T1DM. Good metabolic control and a physiological GH-IGF-I axis induced a completely normal growth in all three groups. Height SDS was not different in the three groups compared with control subjects, showing a normal growth in children with intensive insulin therapy and normal final height in all subjects with diabetes when compared with controls.

These results suggest that intensive insulin therapy starting from the onset of diabetes might prevent the induction of abnormalities of the GH-IGF-I-IGFBP-3 axis potentially achieving near-normal portal insulin concentrations and thereby leading to normal IGF-I and IGFBP-3 levels and physiological growth in children and adolescents with T1DM.

\section{Conclusions}

Normal growth is one of the major goals in the treatment of children with T1DM. Progress in knowledge of the physiopathology of diabetes related to growth impairment, and improvement in diabetes management and particularly the use of new insulin regimens in newly diagnosed patients with T1DM, has substantially improved the prognosis for growth. Modern insulin treatment may prevent abnormalities of the mechanisms by which $\mathrm{GH}$ brings about growth and allow normal growth in children with diabetes.

\section{References}

1 Guest CM. The Mauriac syndrome: dwarfism, hepatomegaly and obesity with juvenile diabetes mellitus. Diabetes 19532 415-417.

2 Salardi S, Tonioli S, Tassoni P, Tellarini M, Mazzanti L \& Cacciari E. Growth and growth factors in diabetes mellitus. Archives of Diseases in Childhood 198762 57-62.
3 Penfold J, Chase HP, Marshall G, Walravens CF, Walravens PA \& Garg SK. Final adult height and its relationship to blood glucose control and microvascular complications in IDDM. Diabetic Medicine $199512129-133$.

4 Donaghue KC, Kordonouri O, Chan A \& Silink M. Secular trends in growth in diabetes: are we winning? Archives of Diseases in Childhood $2003 \mathbf{8 8} 151-154$.

5 Kember NF. Cell kinetics and the control of growth in long bones. Cell Tissue Kinetics 197811 477-485.

6 Kember NF. Cell kinetics and the control of bone growth. Acta Paediatrica 199382 (Suppl 391) 61-65.

7 Salmon WD Jr \& Daughaday WH. A hormonally controlled serum factor which stimulates sulfate incorporation by cartilage in vitro. Journal of Laboratory and Clinical Medicine $1957 \mathbf{4 9} 825-836$.

8 Salmon WD Jr \& Daughaday WH. A hormonally controlled serum factor which stimulates sulfate incorporation by cartilage in vitro. Journal of Laboratory and Clinical Medicine $1990116408-419$.

9 Jones JI \& Clemmons DR. Insulin-like growth factors and their binding proteins: biological actions. Endocrine Reviews 199516 3-34.

10 Blum W \& Ranke MB. Insulin-like growth factor binding proteins (IGFBPs) with special reference to IGFBP-3. Acta Paediatrica Scandinavica 1990 (Suppl 367) 55-62.

11 Hwa V, Oh Y \& Rosenfeld RG. The insulin-like growth factor-binding protein (IGFBP) superfamily. Endocrine Reviews 199920 $761-787$.

12 Baxter RC \& Turtle JR. Regulation of hepatic growth hormone receptors by insulin. Biochemical and Biophysical Research Communications $1978 \mathbf{8 4} 350-357$.

13 Daughaday WH, Phillips LS \& Mueller MC. The effects of insulin and growth hormone on the release of somatomedin by the isolated rat liver. Endocrinology 197698 1214-1219.

14 Maes M, Underwood LE \& Ketelslegers JM. Low serum somatomedin-C in insulin-dependent diabetes: evidence for a postreceptor mechanism. Endocrinology $1986118377-382$.

15 Cotterill AM, Cowell CT \& Silink M. Insulin and variation in glucose levels modify the secretion rates of the growth hormoneindependent insulin-like growth factor binding protein-1 in the human hepatoblastoma cell line Hep G2. Journal of Endocrinology 198912 R $17-\mathrm{R} 20$.

16 Holly JM, Biddlecombe RA, Dunger DB, Edge JA, Amiel SA, Howell R, Chard T, Rees LH \& Wass JA. Circadian variation of GH-independent IGF-binding protein in diabetes mellitus and its relationship to insulin. A new role for insulin? Clinical Endocrinology $198829667-675$.

17 Holly JM, Dunger DB, Edge JA, Smith CP, Chard T \& Wass JA. Insulin-like growth factor binding protein-1 levels in diabetic adolescents and their relationship to metabolic control. Diabetic Medicine 19907 618-623.

18 Dunger DB \& Cheetham TD. Growth hormone-insulin-like growth factor-I axis in insulin-dependent diabetes mellitus. Hormone Research $1996 \mathbf{4 6} 2-6$. 
19 Holl RW, Siegler B, Scherbaum WA \& Heinze E. The serum growth hormone-binding protein is reduced in young patients with insulin-dependent diabetes mellitus. Journal of Clinical Endocrinology and Metabolism 199376 165-167.

20 Menon RK, Arslanian S, May B, Cutfield WS \& Sperling MA. Diminished growth hormone-binding protein in children with insulin-dependent diabetes mellitus. Journal of Clinical Endocrinology and Metabolism 199274 934-938.

21 Arslanian SA, Menon RK, Gierl AP, Heil BV \& Foley TP Jr. Insulin therapy increases low plasma growth hormone binding protein in children with new-onset type 1 diabetes. Diabetic Medicine 1993 $10833-838$.

22 Yakar S, Setser J, Zhao H, Stannard B, Haluzik M, Glatt V, Bouxsein ML, Kopchick JJ \& LeRoith D. Inhibition of growth hormone action improves insulin sensitivity in liver IGF-I-deficient mice. Journal of Clinical Investigation 2004113 96-105.

23 Fowelin J, Attvall S, von Schenck H, Smith U \& Lager I. Characterization of the insulin-antagonistic effect of growth hormone in man. Diabetologia 199134 500-506.

24 Davidson MB. Effect of growth hormone on carbohydrate and lipid metabolism. Endocrine Reviews 19878 115-131.

25 Rizza RA, Mandarino LJ \& Gerich JE. Effects of growth hormone on insulin action in man. Mechanisms of insulin resistance, impaired suppression of glucose production, and impaired stimulation of glucose utilization. Diabetes 198231 663-669.

26 Bratusch-Marrain PR, Smith D \& DeFronzo RA. The effect of growth hormone on glucose metabolism and insulin secretion in man. Journal of Clinical Endocrinology and Metabolism 1982 $\mathbf{5 5} 973-982$

27 Kahn SE, Prigeon RL, McCulloch DK, Boyko EJ, Bergman RN, Schwartz MW, Neifing JL, Ward WK, Beard JC \& Palmer JP. Quantification of the relationship between insulin sensitivity and beta-cell function in human subjects. Evidence for a hyperbolic function. Diabetes $1993 \mathbf{4 2} 1663-1672$.

28 Acerini CL, Cheetham TD, Edge JA \& Dunger DB. Both insulin sensitivity and insulin clearance in children and young adults with Type I (insulin-dependent) diabetes vary with growth hormone concentrations and with age. Diabetologia $2000 \mathbf{4 3}$ $61-68$.

29 Edge JA, Matthews DR \& Dunger DB. The dawn phenomenon is related to overnight growth hormone release in adolescent diabetics. Clinical Endocrinology 199033 729-737.

30 Thirone AC, Carvalho CR \& Saad MJ. Growth hormone stimulates the tyrosine kinase activity of JAK2 and induces tyrosine phosphorylation of insulin receptor substrates and Shc in rat tissues. Endocrinology 1999140 55-62.

31 VanderKuur J, Allevato G, Billestrup N, Norstedt G \& Carter-Su C. Growth hormone-promoted tyrosyl phosphorylation of SHC proteins and SHC association with Grb2. Journal of Biological Chemistry $1995 \mathbf{2 7 0} 7587-7593$.

32 Vanderkuur JA, Butch ER, Waters SB, Pessin JE, Guan KL \& Carter-Su C. Signaling molecules involved in coupling growth hormone receptor to mitogen-activated protein kinase activation. Endocrinology 1997138 4301-4307.

33 Kilgour E, Gout I \& Anderson NG. Requirement for phosphoinositide 3-OH kinase in growth hormone signalling to the mitogen-activated protein kinase and p70s6k pathways. Biochemical Journal $1996315517-522$.

34 Argetsinger LS, Hsu GW, Myers MG Jr, Billestrup N, White MF \& Carter-Su C. Growth hormone, interferon-gamma, and leukemia inhibitory factor promoted tyrosyl phosphorylation of insulin receptor substrate-1. Journal of Biological Chemistry $1995 \mathbf{2 7 0}$ 14685-14692.

35 Argetsinger LS, Norstedt G, Billestrup N, White MF \& Carter-Su C. Growth hormone, interferon-gamma, and leukemia inhibitory factor utilize insulin receptor substrate-2 in intracellular signaling. Journal of Biological Chemistry $1996 \quad \mathbf{2 7 1}$ 29415-29421.

36 Adams TE, Adams TE, Hansen JA, Starr R, Nicola NA, Hilton DJ \& Billestrup N. Growth hormone preferentially induces the rapid, transient expression of SOCS-3, a novel inhibitor of cytokine receptor signaling. Journal of Biological Chemistry 1998273 1285-1287.

37 Mooney RA, Senn J, Cameron S, Inamdar N, Boivin LM, Shang Y \& Furlanetto RW. Suppressors of cytokine signaling-1 and -6 associate with and inhibit the insulin receptor. A potential mechanism for cytokine-mediated insulin resistance. Journal of Biological Chemistry $200127625889-25893$.

38 Peraldi P, Filloux C, Emanuelli B, Hilton DJ \& Van Obberghen E. Insulin induces suppressor of cytokine signaling-3 tyrosine phosphorylation through Janus-activated kinase. Journal of Biological Chemistry $200127624614-24620$.

39 Dey BR, Furlanetto RW \& Nissley P. Suppressor of cytokine signaling (SOCS)-3 protein interacts with the insulin-like growth factor-I receptor. Biochemical and Biophysical Research Communications 2000278 38-43.

40 Emanuelli B, Peraldi P, Filloux C, Sawka-Verhelle D, Hilton D \& Van Obberghen E. SOCS-3 is an insulin-induced negative regulator of insulin signaling. Journal of Biological Chemistry 2000275 15985-15991.

41 Rui L, Yuan M, Frantz D, Shoelson S \& White MF. SOCS-1 and SOCS-3 block insulin signaling by ubiquitin-mediated degradation of IRS1 and IRS2. Journal of Biological Chemistry 2002 277 42394-42398.

42 Kawazoe Y, Naka T, Fujimoto M, Kohzaki H, Morita Y, Narazaki M, Okumura K, Saitoh H, Nakagawa R, Uchiyama Y, Akira S \& Kishimoto T. Signal transducer and activator of transcription (STAT)induced STAT inhibitor 1 (SSI-1)/suppressor of cytokine signaling 1 (SOCS1) inhibits insulin signal transduction pathway through modulating insulin receptor substrate 1 (IRS-1) phosphorylation. Journal of Experimental Medicine 2001193 263-269.

43 Chiarelli F, Santilli F \& Mohn A. Role of growth factors in the development of diabetic complications. Hormone Research 2000 $5353-67$

44 Quattrin T, Thrailkill K, Baker L, Kuntze J, Compton P \& Martha P. Improvement of $\mathrm{HbAlc}$ without increased hypoglycemia in adolescents and young adults with type 1 diabetes mellitus treated with recombinant human insulin-like growth factor-I and insulin. rhIGF-I in IDDM Study Group. Journal of Pediatric Endocrinology and Metabolism 200114 267-277.

45 Thrailkill K, Quattrin T, Baker L, Litton J, Dwigun K, Rearson M, Poppenheimer M, Kotlovker D, Giltinan D, Gesundheit N \& Martha P Jr. Dual hormonal replacement therapy with insulin and recombinant human insulin-like growth factor (IGF)-I in insulin-dependent diabetes mellitus: effects on the growth hormone/IGF/IGF-binding protein system. Journal of Clinical Endocrinology and Metabolism 199782 1181-1187.

46 Acerini CL \& Dunger DB. Insulin-like growth factor-I for the treatment of type 1 diabetes. Diabetes, Obesity and Metabolism 20002 335-343.

47 Crowne EC, Samra JS, Cheetham T, Acerini CL, Watts A, Holly JM \& Dunger DB. The role of IGF-binding proteins in mediating the effects of recombinant human IGF-I on insulin requirements in type 1 diabetes mellitus. Journal of Clinical Endocrinology and Metabolism 200186 3686-3691.

48 Smith LE, Shen W, Perruzzi C, Soker S, Kinose F, Xu X, Robinson G, Driver S, Bischoff J, Zhang B, Schaeffer JM \& Senger DR. Regulation of vascular endothelial growth factor dependent retinal neovascularization by insulin like growth factor 1 receptor. Nature Medicine 19995 1390-1395.

49 Kondo T, Vicent D, Suzuma K, Yanagisawa M, King GL, Holzenberger M \& Kahn CR. Knockout of insulin and IGF-I receptors on vascular endothelial cells protects against retinal neovascularization. Journal of Clinical Investigation 2003111 1835-1842.

50 Verrotti A, Cieri F, Petitti MT, Morgese G \& Chiarelli F. Growth hormone and IGF-I in diabetic children with and without microalbuminuria. Diabetes, Nutrition and Metabolism $199912271-276$.

51 Chiarelli F, Spagnoli A, Basciani F, Tumini S, Mezzetti A, Cipollone F, Cuccurullo F, Morgese G \& Verrotti A. Vascular endothelial growth factor (VEGF) in children, adolescents and young 
adults with type 1 diabetes mellitus: relation to glycaemic control and microvascular complications. Diabetic Medicine 200017 650-656.

52 Santilli F, Spagnoli A, Mohn A, Tumini S, Verrotti A, Cipollone F, Mezzetti A \& Chiarelli F. Increased vascular endothelial growth factor serum concentrations may help to identify patients with onset of type 1 diabetes during childhood at risk for developing persistent microalbuminuria. Journal of Clinical Endocrinology and Metabolism 200186 3871-3876.

53 Price DE \& Burden AC. Growth of children before onset of diabetes. Diabetes Care 199215 1393-1395.

54 Drayer NM. Height of diabetic children at onset of symptoms. Archives of Diseases in Childhood $197449616-620$.

55 Edelsten AD, Hughes IA, Oakes S, Gordon IR \& Savage DC. Height and skeletal maturity in children with newly-diagnosed juvenileonset diabetes. Archives of Diseases in Childhood 198156 40-44.

56 Bognetti E, Riva MC, Bonfanti R, Meschi F, Viscardi M \& Chiumello G. Growth changes in children and adolescents with short-term diabetes. Diabetes Care 199821 1226-1229.

57 Wise JE, Kolb EL \& Sauder SE. Effect of glycemic control on growth velocity in children with IDDM. Diabetes Care 199215 826-830.

58 Holl RW, Heinze E, Seifert M, Grabert M \& Teller WM. Longitudinal analysis of somatic development in paediatric patients with IDDM: genetic influences on height and weight. Diabetologia $199437925-929$.

59 Cianfarani S, Bonfanti R, Manca Bitti ML, Germani S, Boemi S, Chiumello G \& Boscherini B. Growth and insulin-like growth factors in children with insulin-dependent diabetes mellitus at the onset of disease: evidence for normal growth, age dependency of the IGF system alterations, and presence of a small (approximately 18-kilodalton) IGF-binding protein-3 fragment in serum. Journal of Clinical Endocrinology and Metabolism 2000 $854162-4167$.

60 Du Caju MV, Rooman RP \& op de Beeck L. Longitudinal data on growth and final height in diabetic children. Pediatric Research $199538607-611$.

61 Brown M, Ahmed ML, Clayton KL \& Dunger DB. Growth during childhood and final height in type 1 diabetes. Diabetic Medicine $199411182-187$.

62 Songer TJ, LaPorte RE, Tajima N, Orchard TJ, Rabin BS, Eberhardt MS, Dorman JS, Cruickshanks KJ, Cavender DE \& Becker DJ. Height at diagnosis of insulin-dependent diabetes in patients and their non-diabetic family members. British Medical Journal 1986292 1419-1422.

63 Thon A, Heinze E, Feilen KD, Holl RW, Schmidt H, Koletzko S, Wendel U \& Nothjunge J. Development of height and weight in children with diabetes mellitus: report on two prospective multicentre studies, one cross-sectional, one longitudinal. European Journal of Pediatrics $1992151258-262$.

64 Gunczler P, Lanes R, Esaa S \& Paoli M. Effect of glycemic control on the growth velocity and several metabolic parameters of conventionally treated children with insulin-dependent diabetes mellitus. Journal of Pediatric Endocrinology and Metabolism 19969 569-575.

65 Knip M, Tapanainen P, Pekonen F \& Blum WF. Insulin-like growth factor binding proteins in prepubertal children with insulindependent diabetes mellitus. European Journal of Endocrinology $1995133440-444$.

66 Tapanainen P, Kaar ML, Leppaluoto J, Huttunen NP \& Knip M. Normal stimulated growth hormone secretion but low peripheral levels of insulin-like growth factor I in prepubertal children with insulin-dependent diabetes mellitus. Acta Paediatrica $1995 \mathbf{8 4}$ 646-650.

67 Munoz MT, Barrios V, Pozo J \& Argente J. Insulin-like growth factor I, its binding proteins 1 and 3 , and growth hormone-binding protein in children and adolescents with insulin-dependent diabetes mellitus: clinical implications. Pediatric Research 1996 $39992-998$.

68 Taylor AM, Dunger DB, Grant DB \& Preece MA. SomatomedinC/IGF-I measured by radioimmunoassay and somatomedin bioactivity in adolescents with insulin-dependent diabetes compared with puberty matched controls. Diabetes Research 19889 $177-181$.

69 Rogers DG, Sherman LD \& Gabbay KH. Effect of puberty on insulin-like growth factor I and HbA1c in type 1 diabetes. Diabetes Care $1991141031-1035$.

70 Dills DG, Allen C, Palta M, Zaccaro DJ, Klein R \& D’Alessio D. Insulin-like growth factor-I is related to glycemic control in children and adolescents with newly diagnosed insulin-dependent diabetes. Journal of Clinical Endocrinology and Metabolism 1995 80 2139-2143.

71 Bereket A, Lang CH, Blethen SL, Ng LC \& Wilson TA. Insulin treatment normalizes reduced free insulin-like growth factor-I concentrations in diabetic children. Clinical Endocrinology 1996 $45321-326$.

72 Amiel SA, Sherwin RS, Hintz RL, Gertner JM, Press CM \& Tamborlane WV. Effect of diabetes and its control on insulin-like growth factors in the young subject with type I diabetes. Diabetes 1984 33 1175-1179.

73 Rudolf MCJ, Sherwin RS, Markowitz R, Bates SE, Genel M, Hochstadt J \& Tamborlane WV. Effect of intensive insulin treatment on linear growth in the young diabetic patients. Journal of Pediatrics $1982101333-339$.

74 Clark PA, Clarke WL, Pedadda S, Reiss A, Langlois C, NievesRivera F \& Rogol AD. The effects of pubertal status and glycemic control on the growth hormone-IGF-I axis in boys with insulindependent diabetes mellitus. Journal of Pediatric Endocrinology and Metabolism $199811427-435$.

75 Batch JA, Baxter RC \& Werther G. Abnormal regulation of insulin-like growth factor binding proteins in adolescents with insulin-dependent diabetes. Journal of Clinical Endocrinology and Metabolism 199173 964-968.

76 Cinaz P, Kendirci M, Kurtoglu S, Gokcora N, Buyan N, Yavuz I \& Demir A. Serum levels of insulin-like growth factor-I and insulinlike growth factor binding protein-3 in children with insulindependent diabetes mellitus. Journal of Pediatric Endocrinology and Metabolism 19969 475-482.

77 Amiel SA, Sherwin RS, Simonson DC, Lauritano AA \& Tamborlane WV. Impaired insulin action in puberty. A contributing factor to poor glycemic control in adolescents with diabetes. New England Journal of Medicine 1986315 215-219.

78 Bloch CA, Clemons P \& Sperling MA. Puberty decreases insulin sensitivity. Journal of Pediatrics $1987110481-487$.

79 Scottish Study Group for the Care of the Young Diabetic. Factors influencing glycemic control in young people with type 1 diabetes in Scotland: a population-based study (DIABAUD2). Diabetes Care $200124239-244$

80 Edge JA, Dunger DB, Matthews DR, Gilbert JP \& Smith CP. Increased overnight growth hormone concentrations in diabetic compared with normal adolescents. Journal of Clinical Endocrinology and Metabolism 199071 1356-1362.

81 Asplin CM, Faria AC, Carlsen EC, Vaccaro VA, Barr RE, Iranmanesh A, Lee MM, Veldhuis JD \& Evans WS. Alterations in the pulsatile mode of growth hormone release in men and women with insulin-dependent diabetes mellitus. Journal of Clinical Endocrinology and Metabolism 198969 239-245.

82 Batch JA \& Werther GA. Changes in growth hormone concentrations during puberty in adolescents with insulin-dependent diabetes. Clinical Endocrinology 199236 411-416.

83 Press M, Tamborlane WV \& Sherwin RS. Importance of raised growth hormone levels in mediating the metabolic derangements of diabetes. New England Journal of Medicine 1984 $310810-815$.

84 Arslanian S, Heil B, Becker D \& Drash AL. Sexual dimorphism in insulin sensitivity in adolescents with insulin-dependent diabetes mellitus. Journal of Clinical Endocrinology and Metabolism 199172 920-926.

85 Danne T, Kordonouri O, Enders I \& Weber B. Factors influencing height and weight development in children with diabetes. Results of the Berlin Retinopathy Study. Diabetes Care 199720 281-283. 
86 Jivani SK \& Rayner PH. Does control influence the growth of diabetic children? Archives of Diseases in Childhood $1973 \mathbf{4 8}$ 109-115.

87 Ahmed ML, Connors MH, Drayer NM, Jones JS \& Dunger DB. Pubertal growth in IDDM is determined by HbA1c levels, sex, and bone age. Diabetes Care 199821 831-835.

88 Tattersall RB \& Pyke DA. Growth in diabetic children at onset of symptoms. Lancet 19732 1105-1109.

89 Vanelli M, de Fanti A, Adinolfi B \& Ghizzoni L. Clinical data regarding the growth of diabetic children. Hormone Research $19923765-69$

90 Radetti G, Paganini C, Antoniazzi F, Pasquino B, Valentini R, Gentili L \& Tato L. Growth hormone-binding proteins, IGF-I and IGF-binding proteins in children and adolescents with type 1 diabetes mellitus. Hormone Research 199747 110-115.

91 Clayton KL, Holly JM, Carlsson LM, Jones J, Cheetham TD, Taylor AM \& Dunger DB. Loss of the normal relationships between growth hormone, growth hormone-binding protein and insulinlike growth factor-I in adolescents with insulin-dependent diabetes mellitus. Clinical Endocrinology $1994 \mathbf{4 1} 517-524$.
92 Massa G, Dooms L, Bouillon R \& Vanderschueren-Lodeweyckx M. Serum levels of growth hormone-binding protein and insulin-like growth factor I in children and adolescents with type 1 (insulindependent) diabetes mellitus. Diabetologia 199336 239-243.

93 Dunger DB. Insulin and insulin-like growth factors in diabetes mellitus. Archives of Diseases in Childhood 199572 469-471.

94 Salerno M, Argenziano A, Di Maio S, Gasparini N, Formicola S, De Filippo G \& Tenore A. Pubertal growth, sexual maturation, and final height in children with IDDM. Effects of age at onset and metabolic control. Diabetes Care 199720 721-724.

95 Holl RW, Grabert M, Heinze E, Sorgo W \& Debatin KM. Age at onset and long-term metabolic control affect height in type-1 diabetes mellitus. European Journal of Pediatrics $1998157972-977$.

Received 18 May 2004

Accepted 5 August 2004 